African Crop Science Journal by African Crop Science Society is licensed under a Creative Commons Attribution 3.0 Uganda License. Based on a work at www.ajol.info/ and www.bioline.org.br/cs DOI: https://dx.doi.org/10.4314/acsj.v27i4.11

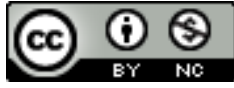

\title{
PROSPECTS OF QUALITY PROTEIN MAIZE AS FEED FOR INDIGENOUS CHICKENS IN ZIMBABWE: A REVIEW
}

\author{
T.N. BIDI, E. GASURA ${ }^{1}$, S. NCUBE, P.T. SAIDI and M. MAPHOSA ${ }^{2}$
}

Department of Animal Science, University of Zimbabwe, Box MP167, Harare, Zimbabwe ${ }^{1}$ Department of Crop Science, University of Zimbabwe, Box MP167, Harare, Zimbabwe ${ }^{2}$ Department of Crop and Soil Sciences, Lupane State University, Box 170, Lupane, Zimbabwe

Corresponding author: gasurae@yahoo.com

(Received 5 November 2018; accepted 22 November 2019)

\begin{abstract}
Indigenous chickens (IC) play an important role in African rural household settings, particularly in improving their livelihoods. However, IC production is characterised by low productivity due to poor quality and quantity of feed, compounded by poor management practises. This dire situation is aggravated by the fact that IC are raised under extensive systems, supplemented with meagre grain supplements. They are a hardy poultry species and as a result most farmers assume that their nutritional requirements can be met through scavenging. To the contrary, analysis of crop contents has shown that IC nutritional intake levels are often below optimum for production. To enhance the productivity of IC, there is urgent need to explore the use of alternative nutritionally rich feed stuffs. One of such ingredients is Quality Protein Maize (QPM). Quality protein maize contains elevated levels of lysine and tryptophan, compared to non-QPM. The objective of this article is to review the prospects of QPM as feed for IC, through a strengths, weaknesses, opportunities and threats analysis. Due to its superior nutritional quality, QPM has the potential to enhance growth rate, carcass characteristics and immunity of indigenous chickens. However, QPM is still a new technology in Zimbabwe; most farmers are not aware of its existence. There is, therefore, need for policies and infrastructural adjustments to promote its widespread adoption. Furthermore, there is need for feeding trials as they provide concrete evidence of the benefits of this kind of maize.
\end{abstract}

Key Words: Carcass quality, quality protein maize, supplementary feed

\section{RÉSUMÉ}

Les poulets indigènes $(\mathrm{CI})$ jouent un rôle important dans les ménages ruraux africains, en particulier pour améliorer leurs moyens de subsistance. Cependant, la production de circuits intégrés se caractérise par une faible productivité due à la qualité et quantité d'aliment médiocres, aggravées par de mauvaises pratiques de gestion. Cette situation désastreuse est aggravée par le fait que les CI sont cultivées dans le cadre de systèmes étendus, complétés par de maigres suppléments de céréales. C'est une espèce de volaille robuste et, par conséquent, la plupart des agriculteurs pensent que leurs besoins 
nutritionnels peuvent être satisfaits grâce au nettoyage. Au contraire, l'analyse du contenu des cultures a montré que les niveaux d'apport nutritionnel en IC sont souvent inférieurs à l'optimum pour la production. Pour améliorer la productivité des circuits intégrés, il est urgent d'explorer l'utilisation de produits de substitution pour aliments riches en aliments. Un de ces ingrédients est le maïs à protéines de qualité (QPM). QPM contient des niveaux élevés de lysine et de tryptophane par rapport au maïs non-QPM. L'objectif de cet article est d'examiner les perspectives de QPM en tant que source pour IC, à travers une analyse SWOT. Grâce à sa qualité nutritionnelle supérieure, le QPM peut potentiellement améliorer le taux de croissance, les caractéristiques de la carcasse et l'immunité des poulets indigènes. Cependant, le QPM est encore une nouvelle technologie au Zimbabwe; la plupart des agriculteurs ne sont pas au courant de son existence. Des politiques et des ajustements d'infrastructures sont donc nécessaires pour promouvoir son adoption à grande échelle. En outre, des essais d'alimentation sont nécessaires car ils fournissent des preuves concrètes des avantages de ce type de maïs.

Mots Clés: Qualité de la carcasse, protéiné de maïs de qualité, aliment complémentaire

\section{INTRODUCTION}

Despite the introduction of the improved, fast growing exotic chickens as a source of white meat in sub-Saharan Africa (SSA), indigenous chickens (1C) remain predominant in most parts, such as Zimbabwe. They contribute $80 \%$ of total poultry production in Africa (Besbes, 2009). Albeit, in small proportions, they are an indispensible source of income and quality protein for the marginalised rural poor (Mwacharo et al., 2007). However, IC productivity is generally low as witnessed by slow growth rates, late maturity and poor egg production per hen per year (Mapiye et al., 2008).

The poor productivity of IC is attributed to poor quality and quantity of feeds compounded by poor management practises (Ayssiwede et al., 2011; Ncobela and Chimonyo, 2015a). Indigenous chickens are raised in a highly integrated crop-livestock system, present in the communal areas of Zimbabwe. These birds scavenge to meet most of their nutritional needs, and occasionally receive meagre grain supplements such as sorghum and maize (Mapiye et al., 2008), with maize being the most dominant feed due to its relative abundance. Protein sources for IC such as insects and worms are scarce, and seasonal (Ncobela and Chimonyo, 2015b). At the same time, maize alone cannot meet all the nutritional requirements of poultry, especially protein, as it is deficient in essential amino acids such as lysine and tryptophan. Deficiency of essential amino acids results in a reduction or cessation of growth or productivity, and a withdrawal of protein from less vital body tissues to maintain body functions (Panda et al., 2014).

Protein content is, therefore, a key limiting factor in IC production under extensive conditions (Kingori et al., 2010). The situation is further exacerbated by the fact that conventional protein sources such as soybean, fish and blood meal are out of reach for smallholder farmers in Zimbabwe, as they are expensive. This discourse reviews the prospects of quality protein maize (QPM) showing strengths, weaknesses, opportunities and threats of QPM usage for Zimbabwe for a period of 10 years, dating back from 2019.

\section{Status of indigenous chicken production in} Zimbabwe. "Indigenous chicken" is a colloquial term that is used to refer to chickens that are adapted to local conditions. Depending on the area, they are synonymously referred to as "rural" (Halima et al., 2007), "village" (Gunaratne et al., 1993), "scavenging" (Mwalusanya et al., 2002) or "traditional chickens" (Cabarles et al., 2012). These birds 
have not been classified into specific breeds, although different ecotypes exist (Khobondo et al., 2015). The different ecotypes are thought to arise as a result of environmental pressures present in different agro-ecological regions (Mtileni et al., 2012). Differences in agro-ecological regions lead to sub-structuring as each ecotype experiences different forces of evolution particularly drift, mutation and natural selection. At least five phenotypes were identified in Zimbabwe and these are black australop, indiana, naked neck, spotted and rambles araucana (Mtileni et al., 2009). There is limited information on the performance of these different ecotypes under different management systems, however, the overall weight of mature chickens range from $2.4 \pm$ $0.7 \mathrm{~kg}$ to $2.7 \pm 0.14 \mathrm{~kg}$ and $1.5 \pm 0.15 \mathrm{~kg}$ to $1.7 \pm 0.17 \mathrm{~kg}$ for the males and females respectively (Mapiye et al., 2008).

The extensive system under which these chickens are raised is generally a low input and low output system. Thus since time immemorial, IC have been considered as the "other" enterprise, with no deliberate effort to improve their productivity. However, recently there has been an upsurge in the demand of organic meat in both developing and developed countries (Okoro et al., 2017). Therefore, the quest to improve the productivity of IC has become inevitable. Improving the quality and quantity of feed has been found to improve the productivity of IC (Asmare et al., 2016).

To ensure optimal feeding of IC, it is necessary to understand their nutrient requirements. The nutrient requirements vary according to the production system as well as stage of growth. Kingori et al. (2007) reported similar crude protein requirements of $18 \%$. The scavenging resource base is variable spatially as well as temporarily, such that nutritional bottlenecks exist particularly during the dry season (Nzioka et al., 2017). Strategic supplementation could be used to improve the productivity of IC (Mapiye et al., 2008). Table 1 shows the effects of supplementary feeding on IC. Despite the fact that IC have a low genetic potential, research has shown that use of supplementary feed helps improve their performance. Supplementary feeding will improve the production until a genetically determined upper limit.

Since farmers already customarily use energy sources, particularly maize, to circumvent feed limitations in IC production, QPM could be used to enhance the quality of supplementary feed. There is need for scientific studies nonetheless, on how to best utilise QPM as feed. There is often lack of information on how to formulate balanced rations, as backed up by scientific recommendations.

Biochemistry and genetics of quality protein maize. In Zimbabwe, maize (Zea mays $\mathrm{L}$.) is the single most important food crop (Machida et al., 2014). It provides at least 36\% of the food calories (Shiferaw et al., 2011) and is also used for livestock feeding. Regrettably, the nutritional value of maize for monogastrics is undermined by the low quantity of essential amino acids, specifically lysine and tryptophan (Dei, 2017). Therefore, monogastrics, especially in rural areas with fewer alternative protein sources, are likely to succumb to protein deficiency.

Quality protein maize, a bio-fortified maize, is a product of the breeding of non-QPM to improve the protein quality (Agrawal and Gupta, 2010). The poor protein profile in maize is a result of the high amount of zeins in the endosperm. Protein in a maize grain is concentrated in the endosperm and in the germ, the latter is superior in both quality and quantity of protein, but unfortunately constitutes a minor portion (12\%) of the maize grain, compared to $82 \%$ occupied by the endosperm (Vasal, 2000). The endosperm is made up of 3\% albumin, 3\% globulin, 34\% gluten and $60 \%$ zein (Sofi et al., 2009). The zein is naturally devoid of lysine and tryptophan, therefore undermines the protein quality of non-QPM. 
TABLE 1. Effects of supplementary feeding on the performance of indigenous chickens

\begin{tabular}{|c|c|c|c|}
\hline Author & Country & Nutrient profile and type of supplements & Results \\
\hline (Dankwa et al., 2002) & Ghana & $\begin{array}{l}\text { In a study, IC were divided into two groups. } \\
\text { One group was given } 30-50 \mathrm{~g} \text { of larvae and the } \\
\text { other was a control group, no supplementary } \\
\text { feed was provided }\end{array}$ & $\begin{array}{l}\text { Supplementation significantly decreased the age at first lay, } \\
\text { increased egg weight and chick weight at } \mathrm{P}<0.05\end{array}$ \\
\hline (Kingori et al., 2007) & Kenya & $\begin{array}{l}\text { In a completely randomised design, IC were } \\
\text { divided into four groups Each group was given } \\
0,1.6,3.2 \text { and } 4.8 \mathrm{~g} \text { of crude protein } \\
\text { supplementation per bird per day }\end{array}$ & $\begin{array}{l}\text { Growth rate and body weight increased with increasing protein } \\
\text { supplementation up to } 3.2 \mathrm{~g} \text { crude protein per bird per day }\end{array}$ \\
\hline (Mutayoba et al., 2012) & Tanzania & $\begin{array}{l}\text { A study to evaluate the effect supplementation } \\
\text { on growth and egg production in free range } \\
\text { chicken. The chickens were allocated to three } \\
\text { treatments which are: (1) Home made; } \\
\text { (2) Commercial supplement; and } \\
\text { (3) Un-supplemented }\end{array}$ & $\begin{array}{l}\text { Supplementation resulted in increased growth rate, feed } \\
\text { conversion ratio and mature weight }(\mathrm{P}<0.05)\end{array}$ \\
\hline (Okitoi et al., 2009) & Kenya & $\begin{array}{l}\text { In a study, the effect of supplementation of IC } \\
\text { with energy and protein was investigated. } \\
\text { The treatments were as follows: } \\
\text { (1) Scavenging with a supplement of maize } \\
\text { meal and soyabean meal; (2) Scavenging with } \\
\text { a supplementation of soyabean meal; } \\
\text { (3) Scavenging without any supplementation; } \\
\text { and (4) Scavenging with a supplement of maize } \\
\text { meal }\end{array}$ & $\begin{array}{l}\text { Supplementation using maize meal in conjunction with } \\
\text { soyabean meal or soyabean meal significantly increased the } \\
\text { amount of nutrient particularly lysine }(\mathrm{P}<0.05) \text {. This resulted } \\
\text { in increased performance in terms of feed intake, growth } \\
\text { rate and mature weight. Supplementation with maize alone, } \\
\text { significantly decreased the amount of lysine in the crop } \\
(\mathrm{P}<0.05) \text {, thus resulted in reduced performance. } \\
\text { Unsupplemented chickens had the lowest performance } \\
(\mathrm{P}<0.05)\end{array}$ \\
\hline
\end{tabular}


The breakthrough in the improvement of protein quality of maize was accomplished through the discovery of a spontaneous mutant with an opaque-2 allele (Mertz et al., 1964). The opaque-2 allele encodes a transcription factor (basic domain-leucine-zipper), which suppresses the production of zeins (Agrawal and Gupta, 2010). This results in a subsequent decrease in the zein fraction and an increase in the non-zein fraction, which is rich in protein (Mertz et al., 1964; Nuss and Tanumihardjo, 2011). However, the opaque- 2 mutant exhibits adverse pleiotropic effects of the mutant as it produces soft chalky kennels, yield loss of up to $25 \%$ and increases susceptibility to pest and fungal attack, all of which are unacceptable to the farmer (Krivanek et al., 2007). The search then continued for hard kernel QPM germplasm. This led to the discovery of modifier genes, which enhanced the kernel quality and reduced the pleiotropic effects of the opaque- 2 mutant (Gupta et al., 2009; Babu and Prasanna, 2014). The modifier genes interact to improve kernel hardiness, appearance and increase density as well as weight.

To date in Zimbabwe, very excellent varieties of QPM like Mama (MQ623) from Mukushi seeds, SC643 from SeedCo and ZS261 from ARDA Seeds have been developed (Nyakurwa et al., 2017). These QPM varieties have been found to yield the same or 10-25\% higher than the non-QPM varieties under the same agronomic conditions (Setimela et al., 2017; Nyakurwa et al., 2018). It is against this background that the impetus to strengthen the utilisation of QPM arises. Much attention has been directed to the utilisation of QPM as food, but there has been comparatively little effort to explore the utilisation of QPM as feed for IC. There is need for research on the benefits of this type of maize as feed for livestock, so as to enhance its widespread adoption as food and feed.

Nutritional value of quality protein maize. Protein requirement in poultry is a function of the amino acid profile, not just the crude protein content, as birds cannot synthesize essential amino acids. In maize based diets, lysine is the major limiting amino acid (Panda et al., 2010). Under commercial production systems, deficiency of this amino acid is offset by the addition of synthetic amino acids or the addition of conventional protein sources such as soybean or fishmeal. This is, however, unsustainable for resource poor farmers as they cannot afford the costly feeds, QPM is an appealing option as it is both an energy and protein source.

Approximately $12 \%$ of maize grown in SSA is used for livestock feeding, with chicken having the highest percentage (Ayssiwede $e t$ al., 2011). This is in agreement with studies conducted by several other workers (Mwalusanya et al., 2002; Badubi et al., 2006; Mtileni et al., 2009; Ayssiwede et al., 2011). Maize was found to be the chief constituent of the crop in IC. In addition to maize, other crop constituents were worms, insects, green leaves and other unidentified plants materials. The authors were in agreement that energy was available throughout the season, but crude protein and amino acids, precisely lysine were deficient throughout the season.

Table 2 shows that lysine is higher during the rainy season, this could be attributed to higher amount of worms during the rainy season, and it is deficient across all other seasons because of the poor quality of feed. Given that smallholder farmers are already using maize to feed their chickens, non-QPM can be substituted by QPM and used to fill the gap where amino acids are in short supply.

The nutritional superiority of QPM over non-QPM in poultry nutrition has been well established (Omage et al., 2009; Panda et al., 2010; Nuss and Tanumihardjo, 2011; Panda et al., 2014). In the studies referenced above, QPM was found to contain between 30 to $55 \%$ more lysine and tryptophan compared to nonQPM. Furthermore, other essential amino acids such as histidine, arginine, methionine aspartic acid and glycine were higher in QPM as compared to non-QPM. 
TABLE 2. Comparison of the nutritional composition of QPM compared to normal maize

\begin{tabular}{lcc}
\hline Parameter & QPM & Non-QPM \\
\hline Crude protein & $9.26 \pm 0.39$ & $8.83 \pm 0.14$ \\
Lysine & $0.33 \pm 0.05$ & $0.23 \pm 0.02$ \\
Tryptophan & $0.81 \pm 0.01$ & $0.6 \pm 0.01$ \\
Methionine & $0.16 \pm 0.02$ & $0.16 \pm 0.02$ \\
Cysteine & $0.26 \pm 0.01$ & $0.18 \pm 0.01$ \\
Threonine & $0.33 \pm 0.02$ & $0.28 \pm 0.03$ \\
Arginine & $0.56 \pm 0.06$ & $0.37 \pm 0.04$ \\
Isoleucine & $0.30 \pm 0.02$ & $0.25 \pm 0.04$ \\
Leucine & $0.85 \pm 0.09$ & $0.98 \pm 0.23$ \\
Valine & $0.48 \pm 0.04$ & $0.38 \pm 0.07$ \\
Histidine & $0.33 \pm 0.01$ & $0.22 \pm 0.02$ \\
\hline
\end{tabular}

Adopted from Panda et al. (2013); QPM = Quality Protein Maize

A decline for some essential amino acids such as glutamic acid, alanine and leucine has been reported due to the balance of the prolamines and zeins in the endosperm (Dei, 2017). Inversely, this decline especially in leucine is considered beneficial as it makes the leucine-isoleucine ratio balanced, which in turn helps to liberate more tryptophan for niacin biosynthesis.

Moreover, QPM has more biological value than non-QPM (Sofi et al., 2009). Biological value is defined as the percentage of digested and absorbed nitrogen in the body (Prasanna et al., 2001; Krivanek et al., 2007). Only $37 \%$ of protein intake from non-QPM is utilised compared to $74 \%$ of the same amount of QPM. This could be particularly advantageous in IC where both feed quality and quantity are inadequate. An increase in nutrient intake will increase growth linearly until a genetically upper limit is reached. It is hypothesized that QPM could go a long way in providing balanced nutrient animal feed due to its superior nutrient composition compared to non-QPM. However, there is need for research to validate the response of IC in a QPM regime.
Advantage of quality protein maize in indigenous chickens. Monogastric animals, in contrast to ruminants need to be supplied with a good supply of essential amino acids, as they cannot manufacture their own amino acids. Lysine, methionine and tryptophan are the three most limiting amino acids in cerealbased diets (Boisen et al., 2000). As such, these have to be provided in the diet; thus escalating costs of feeds. Commercial feed companies in Zimbabwe rely on importing these essential amino acids. Smallholder farmers have no means of purchasing such commodities. Quality protein maize contains balanced quantities of essential amino acids.

Mpofu and Shoniwa (2012) conducted a study to evaluate the effect and efficacy of QPM on pigs. When non-QPM was replaced with QPM at a higher inclusion rate $(72.3 \%)$, significantly higher feed conversion efficiency and feed intake were observed. Similarly studies conducted by Burgoon et al. (1992) and Okai et al. (2001) indicated that feeding pigs with QPM resulted in increase in body weight, feed conversion efficiency and daily weight gain. The authors concluded that QPM has a superior feeding value compared to nonQPM.

Using an isocalorific and isonitrogenous diet Omage et al. (2009) evaluated the effect of replacing non-QPM with QPM at $0,25,50$, 75 and $100 \%$ levels in rabbits. The authors reported no significant difference in total feed intake, weight gain and feed efficiency. However, a significant difference was found in the cost per unit weight.

In a study conducted by Panda et al. (2010), it was observed that when QPM was used to replace non-QPM at 25, 50, 75 and $100 \%$, body weight gain, and feed conversion efficiency were found to improve at $50 \%$ replacement rate. The results obtained at $50 \%$ replacement were comparable with those that were observed when synthetic lysine was added to non-QPM. The authors concluded 
that QPM has a superior feeding value compared to non-QPM. This was attributed to a higher digestibility of essential amino acids in QPM, particularly of lysine and threonine (Panda et al., 2014).

Lysine is key for protein synthesis and muscle accretion. Therefore, due to its higher lysine content, QPM has potential to improve intake, weight gain and feed conversion efficiency. Kingori et al. (2007) indicated that despite the low genetic potential of IC, increasing protein content of their diets improves feed intake, weight gain and feed conversion efficiency. Since the scavenging resource base is deficient in protein, it is unlikely that the IC would attain the desired growth rate (Ncobela and Chimonyo, 2015a). The deficiency of protein reduces feed intake and consequently growth (Panda et al., 2010). This calls for further research to establish the case of IC.

\section{Role of quality protein maize in enhancing} carcass characteristics. Most researchers did not find differences in carcass characteristics on dressed meat yield, giblet, abdominal fat and cut-off parts in broiler chickens when non-QPM was replaced with QPM (Osei et al., 1999; Panda et al., 2010; Panda et al., 2014). However, an increase in the breast meat yield was observed in broiler chickens when non-QPM was replaced with QPM (Panda et al., 2011) The superior response displayed by broilers fed with QPM could be explained by the high content of lysine coupled with a balanced profile of leucineisoleucine ratio in QPM compared to non-QPM maize. Lysine plays an indispensible role in protein synthesis consequently increases muscle growth while higher levels of leucineisoleucine in non-QPM interfere with muscle development (Panda et al., 2014). Compared to IC, broilers genetically, have a high number of breast total RNA, DNA and protein on a weight basis, all of which are positively correlated with muscle growth (Zheng et al., 2009).
There is limited information of the effect of QPM on haematological, serum biochemical indices and immune response in IC. Haematological profiles are important indicators of health and disease in animals, and have become indispensible in the diagnosis, treatment or prediction of many diseases (Walton, 2012). The amount of protein in a diet affects packed cell volume, haemoglobin content, total serum content and humoral response (Panda et al., 2010). Lysine is responsible for the production of cytokines, proliferation of lymphocytes and consequently the optimal functioning of immune system in response to infection. Inadequate lysine supply reduces antibody response and cell mediated immunity in chickens. Quality protein maize could help to reduce the amount of vaccines. This could have far reaching effects especially for rural farmers who cannot afford to purchase vaccines to manage diseases.

Potential economic aspects. Indigenous chickens are a potentially sustainable enterprise among smallholder farmers due to their low cost of production. Under a commercial setup the economic benefit of QPM has mainly hinged on the reduced cost of feeding as it eliminates the use of expensive synthetic amino acids that are added to the feed (Krivanek et al., 2007). There is evidence on the economic impact of QPM in broiler chickens, pigs and rabbits. The replacement of non-QPM with QPM in rabbits, broilers and pigs has been found to result in a 5\%,3.2\% and 5\% decrease in the feeding cost respectively (Omage $e t$ al., 2009; De Groote et al., 2010; Mpofu and Shoniwa, 2012). However, communal farmers do not use whole balanced feed for their chickens. The feed is not compounded to rations, it is given indiscriminately to different age groups, but maize is the primary feed component. Based on literature from elsewhere, it can be hypothesized that QPM will improve the weights and egg production of IC thus translate into a higher income for smallholder farmers. There is need to evaluate 
the economic impact of QPM under such smallholder conditions.

\section{Challenges and threats to the utilisation} of quality protein maize. Despite the nutritional superiority of QPM over non-QPM, there is paucity of information on the production and utilisation of QPM in Zimbabwe, particularly on IC. Majority of farmers are not aware of its existence or benefits (Machida et al., 2014). According to Nyakurwa et al. (2018), commercial QPM seed is currently available in 17 countries in SSA, yet only 200,000 hectares of land are under QPM cultivation in the region. There is need to facilitate the adoption of QPM through information dissemination.

One of the major impediments of QPM is that the opaque- 2 gene that controls the lysine level in maize is a recessive gene, compounded by the fact that maize is an open pollinated crop. Consequently this gene can be easily lost through cross pollination. It is therefore, important that farmers receive adequate extension on how to grow QPM so as to avoid the loss of this impertual gene.

To curb cross pollination, QPM and nonQPM should be isolated when planting. The recommended isolation distance is 200 to 400 m (Tandzi et al., 2017). However, this exerts pressure on the already limited land resources among growers. Therefore, isolation could be done using different planting dates, either through early or late planting, using varieties of different maturity groups.

The issue of traceability is another drawback in the utilisation of QPM as a feed component. Since farmers grow more than one type of maize seed in Zimbabwe, the QPM and the non-QPM will have to be kept separately. It may be easy for breeders to separate QPM, but might not necessarily be easy for farmers to distinguish between the two. There is need for labelling and record keeping in order to avoid the mixing of QPM and non-QPM. The QPM and non-QPM should be packed and labelled to prevent mixing of maize through the various stages of the value chain such as the farm gate, transport and during storage.

Lack of a premium price for QPM has been cited as one the challenges to widespread adoption of QPM in Zimbabwe (Gregory and Sewando, 2013). There is no incentive, such as higher profit margins for farmers to grow QPM. This is probably because the supply of QPM is supply driven as opposed to being demand driven (Hellin and Erenstein, 2009). Yet most of the protein used in the feed industry is imported, there is need to create synergies between maize growers and feed manufactures through possibilities of contract farming. Moreover, so far maize is currently being used as food, and this could lead to competition between chickens and human beings. The use of non-conventional feedstuffs has since gained a lot of interest to reduce humanlivestock completion (Ncobela and Chimonyo et al., 2015a). Since maize is the staple and yields continue to dwindle (Kafesu et al., 2018), the idea has to promote feedstuffs, particularly nonconventional feedstuffs, with less competition with human beings. However nonconventional feedstuffs such as leaf meals are variable in nutrient level and quality, and contain naturally occurring antinutritional factors. This makes it difficult to formulate diets (Cowieson, 2005). In addition the research and development of nonconventional feedstuffs is still lagging behind. Therefore the use of maize of in poultry diets is still compelling. There is need for feeding trials to investigate the effect of QPM on growth and carcass quality of IC.

Policies to strengthen the utilisation of quality protein maize. Widespread adoption of QPM is low, despite some of the efforts to improve dissemination of QPM by organisations, such as Welthungerhilfe and Mukushi seeds. There is, therefore, need for the Government of Zimbabwe to implement policies that could help to strengthen the utilisation of QPM. One of the innovations 
could be through the use of the command agriculture programme. The command agriculture programme was implemented by the Government of Zimbabwe at the start of the 2016-2017 farming season so as to ensure food self-sufficiency. The scheme provides farmers with access to credit so that they can get access to inputs such as seeds and fertilisers with an agreement to pay for the inputs after harvesting. The Government could make it mandatory for the farmers to allocate a certain hectarage of at least $10 \%$ to the production of QPM and provide subsidised seeds and fertilisers to promote its cultivation.

To ensure adequate supply of QPM, the Government of Zimbabwe could make it mandatory for the seed companies to produce at least one variety of QPM (Nyakurwa et al., 2017). Quality protein maize technology could also be included in the national extension programme. The Government has extension services across all the provinces in Zimbabwe, which could create opportunities for QPM technology awareness. The Grain Marketing Board of Zimbabwe (GMB), through Statutory Instrument 145 of 2019, has regulated the sale of maize, making it the sole buyer and distributor of maize. This could help promote the growing of QPM, by offering premium price.

\section{CONCLUSION}

It can be concluded that QPM is a potential source of feed for indigenous IC, since it has a well-balanced amino acid profile, which still needs research for IC. From the literature presented, QPM has been used successfully as a component of feed in broilers, pigs and rabbits. In each case QPM has been found to result in increased growth rate, increased breast weight and reduction in the cost of feed. However, there is a paucity of information on systematic research on the nutritive value and levels of inclusion of QPM in IC diets. There is, therefore, need for sustained assessment of the nutritive value of conventional feeds incorporating QPM in order to find out the best ways of utilising it as a protein source in diets of IC. Quality protein maize is still a new technology in Zimbabwe and most farmers are not aware of its benefits. It is therefore recommended that the Government of Zimbabwe puts into practise policies that promote its use as both feed and food.

\section{ACKNOWLEDGEMENT}

This study was funded by the Regional Universities Forum for Capacity Building in Agriculture (RUFORUM). Grant number GRG-2015-131.

\section{REFERENCES}

Agrawal, P. and Gupta, H. 2010. Enhancement of protein quality of maize using biotechnological options. Animal Nutrition and Feed Technology 10(spl):79-91.

Asmare, B., Demeke, S., Tolemariam, T., Tegegne, F., Wamatu, J. and Rischkowsky, B. 2016. Determinants of the utilization of desho grass (Pennisetum pedicellatum) by farmers in Ethiopia. Tropical GrasslandsForrajes Tropicales 4(2):112-121.

Ayssiwede, S.B., Zanmenou, J., Issa, Y., Hane, M., Dieng, A., Chrysostome, C., Houinato, M., Hornick, J.-L. and Missohou, A. 2011. Nutrient composition of some unconventional and local feed resources available in Senegal and recoverable in indigenous chickens or animal feeding. Pakistan Journal of Nutrition 10(8):707-717.

Babu, R. and Prasanna, B. 2014. Molecular breeding for quality protein maize (QPM). Genomics of plant genetic resources. Springer: 489-505.

Badubi, S., Rakereng, M. and Marumo, M. 2006. Morphological characteristics and feed resources available for indigenous chickens in Botswana. Livestock Research for Rural Development 18(1):205-211. 
Besbes, B. 2009. Genotype evaluation and breeding of poultry for performance under sub-optimal village conditions. World's Poultry Science Journal 65(2):260-271.

Boisen, S., Hvelplund, T. and Weisbjerg, M.R. 2000. Ideal amino acid profiles as a basis for feed protein evaluation. Livestock Production Science 64(2-3):239-251.

Burgoon, K., Hansen, J., Knabe, D. and . Bockholt, A. 1992. Nutritional value of quality protein maize for starter and finisher swine. Journal of Animal Science 70(3):811-817.

Cabarles, J., Lambio, A., Vega, S., Capitan, S. and Mendioro, M. 2012. Distinct morphological features of traditional chickens (Gallus gallus domesticus L.) in Western Visayas, Philippines. Animal Genetic Resources/Resources génétiques animales/Recursos genéticos animales 5(1):73-87.

Cowieson, A.J. 2005. Factors that affect the nutritional value of maize for broilers. Animal Feed Science and Technology 119(3-4):293-305.

Dankwa, D., Nelson, F., Oddoye, E. and Duncan, J. 2002. Housefly larvae as a feed supplement for rural poultry. Ghana Journal of Agricultural. Science 35:185187.

De Groote, H., Nyanamba, T. and Wahome, R. 2010. Quality protein maize for the feed industry in Kenya. Outlook on Agriculture 39(4):291-298.

Dei, H.K. 2017. Assessment of maize (Zea mays) as Feed Resource for Poultry, Poultry Science, In Tech.

Gregory, T. and Sewando, P. 2013. Determinants of the probability of adopting quality protein maize (QPM) technology in Tanzania: A logistic regression analysis. International Journal of Development and Sustainability 2(2):729-746.

Gunaratne, S., Chandrasiri, A., Hemalatha, W.M. and Roberts, J. 1993. Feed resource base for scavenging village chickens in Sri
Lanka. Tropical Animal Health and Production 25(4):249-257.

Gupta, H.S., Agrawal, P.K., Mahajan, V., Bisht, G., Kumar, A., Verma, P., Srivastava, A., Saha, S., Babu, R. and Pant, M. 2009. Quality protein maize for nutritional security: rapid development of short duration hybrids through molecular marker assisted breeding. Current Science 96(2): 230- 237.

Halima, H., Neser, F.. Van Marle-Koster, E. and De Kock, A. 2007. Village-based indigenous chicken production system in north-west Ethiopia. Tropical Animal Health and Production 39(3):189-197.

Hellin, J. and Erenstein, O. 2009. Maizepoultry value chains in India: implications for research and development. Journal of New Seeds 10(4):245-263.

Kafesu, N., Chikowo, R., Mazarura, U., Gwenzi, W., Snapp, S. and Zingore, S. 2018. Comparative fertilization effects on maize productivity under conservation and conventional tillage on sandy soils in a smallholder cropping system in Zimbabwe. Field Crops Research 218:106114.

Khobondo, J., Muasya, T., Miyumo, S., Okeno, T., Wasike, C., Mwakubambanya, R., Kingori, A. and Kahi, A. 2015. Genetic and nutrition development of indigenous chicken in Africa. Livestock Research for Rural Development 27:122-143.

Kingori, A., Tuitoek, J., Muiruri, H., Wachira, A. and Birech, E. 2007. Protein intake of growing indigenous chickens on free-range and their response to supplementation. International Journal of Poultry Science 6(9):617-621.

Kingori, A., Wachira, A. and Tuitoek, J. 2010. Indigenous chicken production in Kenya: a review. International Journal of Poultry Science 9(4):309-316.

Krivanek, A.F., De Groote, H., Gunaratna, N.S., Diallo, A. and Friesen, D. 2007. Breeding and disseminating quality protein 
maize (QPM) for Africa. African Journal of Biotechnology 6(4):312-324.

Machida, L., Derera, J., Tongoona, P., Langyintuo, A. and MacRobert, J. 2014. Exploration of farmers' preferences and perceptions of maize varieties: Implications on development and adoption of quality protein maize (QPM) varieties in Zimbabwe. Journal of Sustainable Development 7(2):194-207.

Mapiye, C., Mwale, M., Mupangwa, J., Chimonyo, M., Foti, R. and Mutenje, M. 2008. A research review of village chicken production constraints and opportunities in Zimbabwe. Asian-Australian Journal of Animal Science 21(11):1680-1688.

Mertz, E.T., Bates, L.S. and Nelson, O.E. 1964. Mutant gene that changes protein composition and increases lysine content of maize endosperm. Science 145(3629): 279-280.

Mpofu, I.D.T. and Shoniwa A. 2012. The nutritional value of Quality Protein Maize for weaner pigs. Journal of Petroleum \& Environmental Biotechnology 3(5):129133.

Mtileni, B., Muchadeyi, F., Maiwashe, A., Phitsane, P., Halimani, T., Chimonyo, M. and Dzama, K. 2009. Characterisation of production systems for indigenous chicken genetic resources of South Africa. Applied. Animal. Husbandry and Rural Development 2:18-22.

Mtileni, B. J., Muchadeyi, F.C., Maiwashe, A., Chimonyo, M., Mapiye, C. and Dzama, K. 2012. Influence of socioeconomic factors on production constraints faced by indigenous chicken producers in South Africa. Tropical Animal Health and Production 45(1):67-74.

Mutayoba, S., Katule, A., Minga, U. Mtambo, M. and Olsen, J.E. 2012. The effect of supplementation on the performance of free range local chickens in Tanzania. Livestock Research for Rural Development 24(5):93-105.
Mwacharo, J. M., Nomura, K., Hanada, H., Jianlin, H., Hanotte, O. and Amano, T. 2007. Genetic relationships among Kenyan and other East African indigenous chickens. Animal Genetics 38(5):485-490.

Mwalusanya, N., Katule, A., Mutayoba, S., Minga, U., Mtambo, M. and Olsen, J. 2002. Nutrient status of crop contents of rural scavenging local chickens in Tanzania. British Poultry Science 43(1):64-69.

Ncobela, C. and Chimonyo, M. 2015a. Potential of using non-conventional animal protein sources for sustainable intensification of scavenging village chickens: A review. Animal Feed Science and Technology 208:1-11.

Ncobela, C.N. and Chimonyo, M. 2015b. Farmer perceptions on the use of nonconventional animal protein sources for scavenging chickens in semi-arid environments. African Journal of Agricultural Research 10(32):3107-3115.

Nuss, E. T. and Tanumihardjo, S.A. 2011. Quality protein maize for Africa: Closing the protein inadequacy gap in vulnerable populations. Advances in Nutrition: An International Review Journal 2(3):217-224.

Nyakurwa, C., Gasura, E. and Mabasa, S. 2017. Potential for quality protein maize for reducing proteinenergy undernutrition in maize dependent Sub-Saharan African countries: A review. African Crop Science Journal 25(4):521-537.

Nyakurwa, C.S., Gasura, E., Setimela, P.S., Mabasa, S., Rugare, J.T. and Mutsvanga, S. 2018. Reaction of new Quality Protein Maize genotypes to Striga asiatica. Crop Science 58(3):1201-1218.

Nzioka, S., Mungube, E., Mwangi, M., Muhammed. L. and Wambua, J. 2017. The quantity and quality of feed available to indigenous chickens under the scavenging system in semi-arid Eastern Kenya. East African Agricultural and Forestry Journal 82(1):57-69. 
Okai, D., Osei, S. and Tuah, A. 2001. Growth performance and economic traits of pigs fed diets containing either normal maize or Obatanpa-A Quality Protein Maize. Journal of the Kwame Nkrumah University of Science and Technology Kumasi 21(1.2.3):2001-2005.

Okitoi, L., Kabuage, L., Muinga, R. and Badamana, M. 2009. The performance response of scavenging chickens to nutrient intake from scavengeable resources and from supplementation with energy and protein. Livestock Research for Rural Development 21(10):2009-2030.

Okoro, V., Ravhuhali, K., Mapholi, T., Mbajiorgu, E. and Mbajiorgu, C. 2017. Comparison of commercial and locally developed layers' performance and egg size prediction using regression tree method. Journal of Applied Poultry Research 26(4): 476-484.

Omage, J., Agubosi, O., Bawa, G. and Onimisi, P. 2009. Evaluation of the nutritive value of quality protein maize on the growth performance and carcass characteristics of weaner rabbits. Pakistan Journal of Nutrition 8(2):106-111.

Osei, S., Dei, H. and Tuah, A. 1999. Evaluation of quality protein maize as a feed ingredient for layer pullet. Journal of Animal Feed Science 8:181-189.

Panda, A., Raju, M., Rao, S., Lavanya, G., Reddy, E. and Sunder, G.S. 2010. Replacement of normal maize with quality protein maize on performance, immune response and carcass characteristics of broiler chickens. Asian-Australasian Journal of Animal Sciences 23(12):16261631.

Panda, A., Raju, M., Rao, S.R., Lavanya, G., E., Reddy, P.K. and Sunder, G.S. 2011. Nutritional evaluation and utilisation of quality protein maize, Nityashree hybrid maize, and normal maize in broiler chickens. British Journal of Poultry Science 52(5): 632-638.
Panda, A., Prakash, B., Rao, S.R., Raju, M. and Sunder, G.S. 2013. Utilisation of high quality protein maize in poultry. World's Poultry Science Journal 69(4):877-888.

Panda, A., Zaidi, P., Rama Rao, S. and Raju, M. 2014. Efficacy of quality protein maize in meeting energy and essential amino acid requirements in broiler chicken production. Journal of Applied Animal Research 42(2): 133-139.

Prasanna, B., Vasal, S., Kassahun, B. and Singh, N. 2001. Quality protein maize. Current Science 81(10):1308-1319.

Setimela, P., Gasura, E. and Tarekegne, A. 2017. Evaluation of grain yield and related agronomic traits of quality protein maize hybrids in Southern Africa. Euphytica 213(12):289-303.

Shiferaw, B., Prasanna, B.M., Hellin, J. and Bänziger, M. 2011. Crops that feed the world 6. Past successes and future challenges to the role played by maize in global food security. Food Security 3(3): 307-327.

Sofi, P., Wani, S.A., Rather, A. and Wani, S.H. 2009. Quality protein maize (QPM): Genetic manipulation for the nutritional fortification of maize. Journal of Plant Breeding and Crop Science 1(6): 244-253.

Tandzi, L., Mutengwa, C.S., Ngonkeu, E.L.M.,Woïn, N. and Gracen, V. 2017. Breeding for quality protein maize (QPM) varieties: A review. Agronomy 7(4):80.

Vasal, S. 2000. The quality protein maize story. Food and Nutrition Bulletin 21(4):445-450.

Walton, R.M. 2012. Subject based reference values: biological variation, individuality, and reference change values. Veterinary Clinical Pathology 41(2):175-181.

Zheng, Q., Zhang, Y., Chen, Y., Yang, N., Wang, X.J. and Zhu, D. 2009. Systematic identification of genes involved in divergent skeletal muscle growth rates of broiler and layer chickens. BMC Genomics 10(1):87100. 